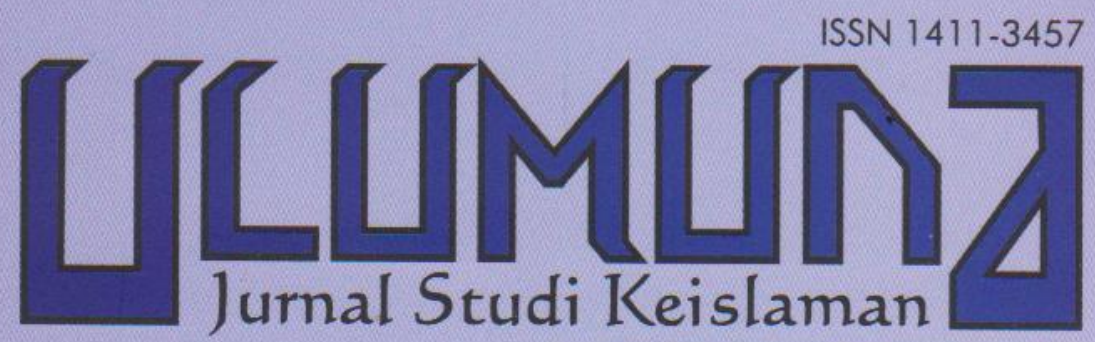

Volume XIII - Nomor 2• Desember 2009

TERAKREDITASI Berdasarkan SK Dirien Dikti Depdiknas Nomor: 65a/DIKTU/Kep/2008

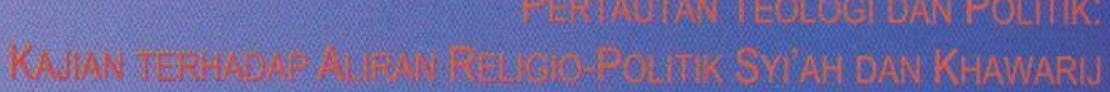

Mustain

TEOLOGI RASIONAL: 2. 6 .02, WLAM MUHAMMAD ABDUH Makrum

TEOLOE LIBERALISME:

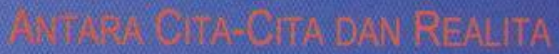
Aswadi

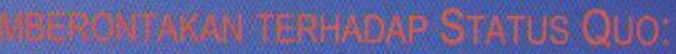

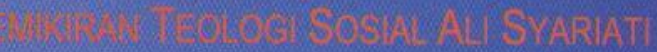
Mukhlis

-1. TONO SAN VISI KEBANGSAAN MASVARAKAT LOMBOK Asnawi

VC. P=R R. PROF-TIK TUAN GURU BSED CAMA OU PULAU LOMBOK Fawaizul Umam 


\section{PEDOMAN TRANSLITERASI}

\begin{tabular}{|c|c|c|c|}
\hline Arab & Latin & Arab & Latin \\
\hline 1 & $=$ & ف & $=\mathbf{f}$ \\
\hline ب & $=$ & ق & $=q$ \\
\hline$\dot{H}$ & $=$ & ك & $=\mathbf{k}$ \\
\hline ج & $=$ & J & $=1$ \\
\hline$\tau$ & $=$ & b & $=\mathrm{m}$ \\
\hline$\dot{\tau}$ & $=\quad \mathrm{kh}$ & $\dot{0}$ & $=\mathbf{n}$ \\
\hline$د$ & $=$ & و & $=\mathbf{w}$ \\
\hline$\dot{j}$ & $d z$ & ○ & $=\mathbf{h}$ \\
\hline J & $=$ & $\&$ & $=$, \\
\hline j & $=$ & ي & $=$ \\
\hline س س & $=$ & & \\
\hline ش ش & sy & \multirow{2}{*}{\multicolumn{2}{|c|}{$\begin{array}{l}\text { Untuk Madd } \\
\text { dan Diftong }\end{array}$}} \\
\hline ص & sh & & \\
\hline ض & dl & i & $=$ â (a panjang) \\
\hline b & th & إي & î (i panjang) \\
\hline ظ & $\mathbf{z h}$ & أو & û (u panjang) \\
\hline$\varepsilon$ & $=$ & آو - - - - & aw \\
\hline$\dot{\varepsilon}$ & gh & آين & ay \\
\hline
\end{tabular}




\section{ISI}

\section{TRANSLITERASI}

\section{ARTIKEL}

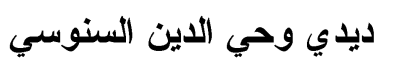

Mustain

Makrum

Halid Al-Kaff

Aswadi

Nurul Anam

Mukhlis

Asnawi

Fawaizul Umam
حفريات علم الكلام ودور المتكلمين 239-268 • في النقافة الإسلامية

Pertautan Teologi dan Politik:

Kajian terhadap Aliran Religio-Politik

Syi'ah dan Khawarij • 269-294

Teologi Rasional:

Telaah atas Pemikiran Kalam

Muhammad Abduh • 295-314

Perspektif Epistemologis

Teologi Islam Liberal • 295-314

Teologi Liberalisme:

Antara Cita-Cita dan Realita • 315-330

Mengurai Benang Kusut

Indikasi Kematian Massal Eksistensi

Tuhan di Abad Globalisasi • 295-314

Islam dan Pemberontakan terhadap

Status Quo: Telaah atas Pemikiran

Teologi Sosial Ali Syariati • 331-356

Paham Teologi dan Visi Kebangsaan

Masyarakat Lombok • 357-382

Tera Ulang Peran Profetik Tuan Guru dalam Konteks Kebebasan Beragama

di Pulau Lombok • 363-416

\section{INDEKS}




\title{
TERA ULANG PERAN PROFETIK TUAN GURU \\ DALAM KONTEKS KEBEBASAN BERAGAMA \\ DI PULAU LOMBOK
}

\author{
Fawaizul Umam*
}

\section{Abstract}

Ulama (Islamic scholars) play important role in culturally paternalistic societies. Their prophetic role is theologically idealized as successors of prophets' risâlah, mission. However, historically speaking, history yet often features reality that differs from their normative role. This paper aims to reevaluate the prophetic role of ulama in Lombok, called tuan guru, in the context of religious freedom praxsis. It is found that what is held by tuan guru in the realm of socio-politico-cultural tend to differ from his own existential theological spirit as one of socio-religious institutions. In the context of the praxis of religious freedom, tuan guru in general tend to play a role as a breeder and booster of anti pluralism discourses. Considering the theological claims of Islam itself as a spreader of mercy for all as well as political-cultural claims that Lombok is religious island, the island of thousand mosques, the realm seems ironic.

Keywords: Tuan Guru, Peran Profetik, Kebebasan Beragama, Paradigma Eksklusif, Kekerasan Atas Nama Agama.

ULAMA, sebagai sebuah institusi sosial-keagamaan, memainkan peran penting terutama dalam masyarakat Muslim yang masih mendekap budaya paternalistik dan memelihara pola kepemimpinan tradisional patron-client. Di berbagai daerah di tanah air, mereka yang tampil sebagai ulama secara sosialkultural disapa akrab dengan aneka sebutan. Di Jawa, misalnya, mereka lazim dipanggil kiai, di Madura galib disebut kiaéh, di masyarakat Sunda dihormati dengan sebutan ajengan, di Sumatera

*Penulis adalah dosen pada Fakultas Dakwah IAIN Mataram. email: fawaizu@yahoo.com. 
biasa dipanggil buya, dan di Lombok disapa takzim dengan sebutan tuan guru.

Secara normatif, peran profetik ulama bertumpu pada spirit teologis sebagai waratsat al-anbiy $\hat{a}$, pewaris para nabi. Mereka diidealisasi sebagai suluh penerang di tengah gelapnya kehidupan. Pancuran ilmu yang terus mencurah di tengah kebodohan umat. Pengawal moralitas di tengah dekadensi yang menggila. Peneguh kebenaran dan keadilan di tengah dehumanisasi sistemik yang tak sudah-sudah. Pencipta damai, penjaga kerukunan, penyubur cinta, penebar rahmat Tuhan bagi seluruh alam (rabmatan li al-âlaminn). Namun, bagaimana di dataran historis-praktis?

Tanya seputar kelindan sisi normatif dan historis dari peran "primordial" ulama itu layak diajukan untuk menera bagaimana peran itu diejawantahkan para figurnya di berbagai daerah, tak terkecuali di Lombok provinsi Nusa Tenggara Barat (NTB). Tulisan ini sendiri, secara keseluruhan, bermaksud hendak menera ulang peran profetik ulama di pulau Lombok, yang (antara lain) direpresentasikan oleh tuan guru, terkhusus dalam konteks praksis kebebasan beragama (religious freedom; freedom of religion or belief) di pulau "seribu masjid" itu. ${ }^{1}$

\section{Ajuan Tesis}

Selama ini terdapat beragam tesis tentang peran profetik ulama dalam konteks dinamika sosial yang terus berubah. Dari sekian itu ada dua tesis besar yang kerap dikutip para antropolog belakangan terutama yang beroperasi di Indonesia dan itu

${ }^{1}$ Selain "Bumi Gora", "Gumi Selaparang", dan juga "laboratorium sosial", "pulau seribu masjid" adalah salah satu sebutan masyhur pulau Lombok. Sebutan ini tak hanya merefleksikan banyaknya masjid di pulau ini, tapi juga penanda demografis bahwa mayoritas penduduk-sejauh merujuk data statistik tahun 2005-beragama Islam, disusul Hindu, Kristen, Katolik, Buddha, dan anutan kepercayaan lokal lain seperti Boda.. Lihat Tabel: 4.4.2. "Banyaknya Umat Beragama Menurut Kabupaten/Kota 2005" dalam Nusa Tenggara Barat Dalam Angka 2005 (Mataram: Badan Pusat Statistik Provinsi NTB, 2005), 141. Sementara dari sisi etnis, mayoritas adalah etnis asli Sasak yang notabene Muslim, diikuti oleh etnis Bali, dan etnis-etnis minoritas seperti Mbojo (Bima), Samawa (Sumbawa), Jawa, Tionghoa, Madura, dan lain-lain. 
membuat keduanya disebut-sebut sebagai grand-theory tentang peran profetik ulama. Dua tesis dimaksud adalah ajuan (1) Clifford Geertz dan (2) Hiroko Horikoshi.

Tesis Geertz tersimpul dari hasil penelitiannya atas kelompok-kelompok "agama Jawa" di Mojokuto Jawa Timur dalam dasawarsa 1950-an yang, antara lain, membimbingnya pada temuan tentang pola keagenan kiai di Jawa. ${ }^{2}$ Menurut Geertz, para kiai di Jawa (subjek penelitiannya) menjalankan suatu pola keagenan yang ia sebut "makelar budaya" (cultural broker). Dengan peran itu kiai tampil sebagai alat penyaring atas arus informasi (dan budaya) yang menyergap masuk ke lingkungan kaum santri. Ia menularkan apa yang dianggap berguna bagi mereka dan membuang apa yang dianggap potensial dapat merusak.

Sementara tesis kedua diajukan Hiroko Horikoshi Roe yang dibangun dari hasil penelitiannya awal 1970-an tentang pola keagenan kiai pada masyarakat Sunda yang antara lain direpresentasikan oleh Ajengan Yusuf Tajri (subjek utama penelitiannya) dari desa Cipari kabupaten Garut, daerah Priangan Jawa Barat. ${ }^{3}$ Menurut Horikoshi, kiai benar-benar berperan aktif dalam perubahan sosial, bukan (sekedar) penyaring informasi seperti diangankan Geertz. Peran aktif itu bukan demi meredam implikasi perubahan yang terjadi, tapi justru karena ingin memelopori perubahan sosial dengan caranya sendiri. Dalam pada itu kiai menawarkan agenda perubahan yang ia anggap sesuai dengan kebutuhan masyarakatnya. Ia berperan

${ }^{2}$ Hasil penelitiannya itu lalu terbit dengan judul The Religion of Java (New York: Free Press, 1960). Khusus tentang pola keagenan kiai Jawa yang berujung pada tesis "kiai sebagai makelar budaya" juga terbit dalam bentuk artikel berjudul "The Javanese Kijaji: The Changing Role of a Cultural Broker," Comparative Studies on Society and History, II, 2 (January, 1960): 22849.

3Penelitian berjudul $A$ Traditional Leader in a Time of Change: The Kijaji and Ulama in West Java itu menjadi disertasi yang mengantar Horikoshi meraih gelar Doctor of Philosophy di bidang Antropologi (1976) pada The Graduate College of the University of Illinois at Urbana-Champaign USA. Versi terjemahannya kemudian diterbitkan dengan judul Kyai dan Perubahan Sosial, ter. Umar Basalim dan Andy Muarly Sunrawa (Jakarta: Perhimpunan Pengembangan Pesantren dan Masyarakat, 1987). 
penuh dalam proses perubahan sosial karena mengerti bahwa proses itu adalah keniscayaan geliat zaman; jadi bukan kurang berperan karena menunda datangnya perubahan lewat proses penyaringan informasi sebagaimana tengara Geertz. ${ }^{4}$

Kedua tesis itu tentu saja dapat digugat. Terutama dalam soal transferabilitasnya sebagai suatu teori sosial, yakni manakala kedua tesis tersebut dihadapkan dengan data-data emik aktual yang selalu berbeda-beda di tiap lanskap budaya atau daerah di Indonesia. Problem ini terutama menyangkut disparitas tempat, waktu, dan situasi sosial hari ini dengan ruang-waktu dan situasi sosial saat penelitian Geertz (Mojokuto Jawa Timur, 1950-an) dan Horikoshi (Garut Jawa Barat, 1970-an) dilangsungkan.

Pada tesis Geertz, misalnya. Peran profetik ulama sebagai penyaring itu akan macet tatkala arus informasi yang masuk begitu deras seiring meningkatnya perkembangan teknologi informasi sehingga tak lagi mungkin disaring oleh sang ulama (kiai, tuan guru). Dalam keadaan demikian, para ulama akan kehilangan signifikansi perannya dalam perubahan sosial yang berlangsung. Lantaran perannya yang sekunder dan tidak kreatif itu, mereka - sebagaimana juga diakui Geertz-akan mengalami kesenjangan budaya (cultural leg) di tengah masyarakatnya. Dan itulah yang tengah terjadi kini, perkembangan cepat teknologi informasi telah membuat mandul peran para ulama sebagai makelar budaya. Karena itu, mengidentifikasi peran ulama hari ini dengan tesis Geertz itu jelas tak lagi memadai (inadequate) teristimewa untuk konteks masyarakat yang mulai mengafirmasi modernitas dan mengalami apa yang disebut the rise of education; kian terdidik (well-educated) suatu masyarakat, kian lemah pula peran ulama sebagai makelar budaya.

Untuk konteks Lombok, tanpa mengabaikan problem transferabilitas itu, kedua tesis dimaksud_dalam batas-batas tertentu (!) — sejatinya tetap dapat dilekatkan pada bagaimana

${ }^{4}$ Tesis Horikoshi yang disandarkan pada penelitiannya selama kuranglebih satu tahun (September 1972/Agustus 1973) itu oleh Gus Dur dipandang telah memperbaiki tesis Geertz yang hanya melihat peran profetik kiai sebagai makelar budaya belaka. Lihat Abdurrahman Wahid, "Benarkah Kyai Membawa Perubahan Sosial?: Sebuah Pengantar," dalam Horikoshi, Kyai...: xi-xx. 
para ulama menjalankan peran profetiknya. Dalam konteks dinamika sosial masyarakat Muslim Sasak Lombok yang relatif masih berkultur tradisional, berkesadaran paternalistik, dan bermental agraris, ${ }^{5}$ para ulama yang lazim disebut tuan guru hadir tidak hanya memainkan peran sebagai makelar budayasebagaimana identifikasi Geertz atas keagenan kiai Jawa. ${ }^{6}$

5 Pengenaan 'mental agraris' ini didasarkan pada kenyataan umum struktur sosial masyarakat Sasak sendiri dengan perspektif teoretisasi pengidentifikasian pembagian kerja secara seksual. Dalam masyarakat agraris, terutama yang berpola pertanian menetap dan mengembangkan tanaman intensif (pola umum sistem pertanian masyarakat Sasak), kaum perempuan umumnya tersisih dari peran-peran produktif secara ekonomis yang didominasi kaum lelaki. Lelaki mengendalikan produksi sedang perempuan terdesak untuk menjalankan fungsi-fungsi kerumahtanggaan. Muncullah apa yang dikenal sebagai "lingkungan publik-domestik" (domesticpublic sphere). Lihat Louise Lamphere, "The Domestic Sphere of Women and the Public World of Man: The Strenghts and Limitations of an Antropological Dictionary," dalam Caroline B. Brettel dan Carolyn F. Sargent (eds.), Gender in Cross-Cultural Perspective (New Jersey: Prentice Hall, 1993): 67-75. Dikotomi publik-domestik itu pada gilirannya melahirkan ideologi gender yang mengacungkan superioritas "alamiah" lelaki di atas inferioritas "alamiah" perempuan. Karena dipandang sebagai makhluk emosional, kecerdasannya di bawah lelaki, dan lemah, maka perempuan tidak diprioritaskan pada sektor pekerjaan yang menuntut kekuatan dan kecerdasan-itu milik lelaki. Kesadaran semacam inilah yang turut memperkuat superioritas tuan guru yang notabene laki-laki. Bdk. identifikasi Kuntowijoyo tentang peran-fungsi ulama pada masyarakat agraris dalam Muslim Tanpa Masjid: Esai-esai Agama, Budaya, dan Politik dalam Bingkai Strukturalisme Transendental (Bandung: Mizan, 2001), 33-9. Masyarakat sedemikian umumnya dapat dijumpai di sejumlah besar masyarakat "dunia ketiga" macam Indonesia. Lihat Stephen K. Sanderson, Sosiologi Makro: Sebuah Pendekatan terhadap Realitas Sosial, ter. Farid Wajidi dan S. Meno (Jakarta: Rajawali Press, 1993), 402-3, 407-8.

${ }^{6}$ Relevansi pengekoran ini didasarkan fakta adanya persamaan dalam beberapa hal antara "kiai" di Jawa (subjek penelitian Geertz) juga "ajengan" di Sunda (subjek penelitian Horikoshi) dan "tuan guru" di Lombok. Setidaknya, ketiga institusi agama itu berada dalam masyarakat yang sama berkultur tradisional plus paternalistik dan bermental agraris. Untuk pengenaan tesis Geertz ini, bandingkan dengan tesis Erni Budiwanti-yang memang cenderung mengapresiasi Geertz-tentang keagenan tuan guru dalam kerangka dakwah di kantong-kantong kebudayaan (enclaves) komunitas Wetu Telu di Bayan Lombok Barat, dalam disertasinya yang lalu terbit dengan judul Islam Sasak: Wetu Telu versus Waktu Lima, ter. Noor Cholis dan 
Namun, lebih jauh, juga berperan sebagai kreator aktif bagi perubahan sosial, yakni memperkenalkan anasir sistem luar sekaligus menggerakkan perubahan dalam masyarakatsebagaimana pembacaan Horikoshi atas hal serupa di Sunda Jawa Barat. ${ }^{7}$ Sebagai makelar budaya, tuan guru berupaya mengaitkan dunia kecil pesantren atau komunitasnya atau dirinya dengan dunia luar. ${ }^{8}$ Mereka mengawasi proses (parokialisasi) parochialization terhadap nilai-nilai universal yang merambahi dunia kecilnya seraya melakukan universalisasi atas nilai-nilai lokal ke dunia luar. Sementara sebagai aktor kreatif dari dinamika sosial, para tuan guru secara relatif efektif menjadi figur panutan atau patron masyarakat. Untuk hal terakhir ini, mereka benarbenar tampil sebagai penentu cetak-biru (blue-print) wacana keagamaan di Lombok. ${ }^{9}$ Mereka menjadi tempat bergantung bagi kegelisahan keagamaan, juga politik, masyarakat Sasak.

Akan tetapi, bagaimana bila peran profetik tuan guru itu dibaca dalam konteks praksis ${ }^{10}$ kebebasan beragama di Lombok

Hairus Salim HS (Yogyakarta: LKíS, 2000). Sedang untuk pengenaan tesis Horikoshi, bandingkan dengan tesis senafas dari penelitian Suprapto (2006) tentang peran profetik tuan guru dalam merevitalisasi kebangkitan civil society melalui pesantren di Lombok. Versi artikelnya termuat di Jurnal Tasamuh Fakultas Dakwah IAIN Mataram Volume IV No. 1 (Desember, 2006): 87108 berjudul "Pesantren dan Pemberdayaan Masyarakat: Menimbang Aktivitas Dakwah bi al-Hal Pesantren di Lombok."

${ }^{7}$ Lihat Horikoshi, Kyai..., 242.

${ }^{8}$ Lihat Geertz, “The Javanese...," 229.

9Tesis "tuan guru sebagai pembentuk dan penentu wacana keagamaan" ini disandarkan pada hasil penelitian penulis sendiri tahun 2003 tentang persepsi gender tuan guru dan efek epistemologisnya bagi masyarakat Muslim Sasak berjudul "Wacana Gender dalam Islam: Studi atas Persepsi Tuan Guru Seputar Relasi Gender Lelaki-Perempuan". Versi artikelnya terbit dengan judul "Membaca Persepsi, Menakar Prospek: Sebuah Catatan Reflektif tentang Ulama dan Pemberdayaan Perempuan di Lombok," dalam Jurnal EGALITA Pusat Studi Gender (PSG) Universitas Islam Negeri (UIN) Malang Volume II Nomor 1 (2007): 1-24.

${ }^{10} \mathrm{Apa}$ yang dimaksud praksis di sini adalah praxis, bukan praktis. Term praxis, yang disebut-sebut diintrodusir Karl Marx, ini mengandung makna aksi manusia yang mencipta perubahan teori untuk kemudian mempengaruhi cara ber-aksi kembali. Tegasnya, dari teori ke aksi untuk kemudian melahirkan teori (baru) lagi, demikian seterusnya; suatu proses circle mengikuti alur filsafat praxis yang dialektik. Lihat F. Wahono 
hari ini? Agaknya pengenaan dua tesis yang memang cenderung apresiatif terhadap peran-peran "primordial" ulama itu dengan berat hati harus ditanggalkan. Penulis, tanpa mengurangi rasa hormat terhadap para tuan guru (ulama), mengajukan (hipo-) tesis yang berpunggungan dengan spirit yang-katakanlahglorifikatif dari tesis dua antropolog besar di atas. Menurut penulis, dalam konteks praksis kebebasan beragama di Lombok mutakhir, tuan guru lebih banyak memainkan peran sebagai pembiak dan penguat wacana-wacana antipluralisme yang potensial mendistorsi cita kebebasan beragama dan memblokade penciptaan kehidupan co-existence antarumat beragama dan juga antarsesama umat Islam sendiri. ${ }^{11}$

Dengan demikian, tuan guru sebagai institusi agama pelanpelan menjadi sebab parsial bagi berlangsungnya disintegrasi antarumat beragama dan antarsesama umat Islam di Lombok. Kebebasan beragama berpotensi bakal terus tercederai, keragaman (baca: pluralisme) sebagai sunnat-Allâh ternegasikan, cita perdamaian dan kehidupan co-existence antarumat beragama plus antarumat Islam sendiri terancam menjadi utopia. Dan itu berarti, secara langsung atau tidak, pilihan peran sedemikian akan membuat agama Islam yang didengung-dengungkan teramat menjunjung kebebasan beragama, pluralisme, toleransi keagamaan (religious tolerance; tasâmuh $\square$ ), dan hak asasi manusia (buman rights) perlahan kehilangan relevansi sosialnya. Kehilangan élan-vital-nya sebagai institusi maupun entitas nilai yang sangat memuliakan manusia dan kemanusiaan bahkan di hadapan Tuhannya, Allah swt.

Alhasil, sebagai (salah satu) institusi agama, tuan guruhingga tingkat tertentu-berpotensi menjadi kendala serius bagi penumbuh-suburan cita ideal kebebasan beragama dan penguatan ide pluralisme agama di bumi Lombok, di kini dan

Nitiprawira, Teologi Pembebasan: Sejarah, Metode, Praksis, dan Isinya (Jakarta: Pustaka Sinar Harapan, 1987), 10.

${ }^{11}$ Tesis ini dilekatkan atas tuan guru in general dengan sama sekali tidak dimaksudkan untuk menggeneralisasi. Tentu saja ada sementara tuan guru yang berpandangan moderat, pluralis, bahkan liberal. TGH Subki Sasaki (Kediri Lombok Barat), TGH Hasanain Juwaini (Narmada Lombok Barat), juga TGH Turmudzi Badaruddin (Bagu Lombok Tengah) adalah sedikit contoh tuan guru yang dapat disebut berkecenderungan demikian. 
masa depan. ${ }^{12}$ Benarkah? Tesis penulis ini akan coba diteguhkan melalui pengajuan data-data faktual di dua level sekaligus, yakni level (1) refleksi teologis yang pekat mewarnai paradigma keagamaan tuan guru dan level (2) aksi-aksi praktis di mana seluruh refleksi teologis itu mereka ejawantahkan. Dua level itu menjadi efektif karena bertemali erat dengan posisi sosial tuan guru sendiri sebagai pembentuk sekaligus penentu sekaligus penafsir (tunggal?) wacana keagamaan di masyarakat Lombok, termasuk wacana kebebasan beragama.

\section{Pembentuk Wacana}

Posisi tuan guru sebagai pembentuk wacana keagamaan itu berkait kausal dengan tergenggamnya apa yang disebut otoritas agama di tangan mereka. ${ }^{13}$ Dengan modus eksistensial masingmasing, mereka meneguhkan sekaligus memanfaatkan otoritas itu baik secara individual maupun institusional. Mulai pembentukan diskursus keagamaan publik hingga ke eksistensialisasi diri di area day-to day politics. Dengan otoritas keagamaan di tangan, sebagaimana ulama di tempat-tempat lain,

${ }^{12}$ Tesis sedemikian mungkin bukan hal baru. Namun, untuk konteks Lombok relatif baru. Apalagi bila melihat trend berbagai penelitian tentang Lombok, terutama yang dilakukan para peneliti lokal. Mereka cenderung terjerembab ke dalam glorifikasi belaka tatkala menyangkut peran sosial tuan guru sebagai institusi agama paling berpengaruh di masyarakat Sasak. Sebut misal penelitian (1) Lukman al-Hakim, Peranan Ulama dalam Pengembangan Syari'at Islam di Lombok, Laporan Penelitian (Mataram: IAIN Sunan Ampel Mataram, 1995); (2) Ahmad Amir Aziz, Pemikiran dan Pola Dakwah TGKH Muhammad Zainuddin Abdul Madjid, Laporan Penelitian (Mataram: P3M STAIN Mataram, 1999); (3) Fathurrahman Muhtar, "Gerakan dan Pemikiran Dakwah Kiai Hamzanwadi dalam Bidang Pendidikan (19341997)," yang versi artikelnya termuat dalam Jurnal Tasamuh Jurusan Dakwah STAIN Mataram Volume II Nomor 1 (Juni, 2004): 77-101; (4) Harapandi Dahri, Wali dan Keramat dalam Persepsi Tradisional dan Modern (Mataram: IAIN Mataram Press, 2004); dan (5) Baharuddin, Nahdlatul Wathan dan Perubahan Sosial (Yogyakarta: Genta Press, 2007).

${ }^{13}$ Identifikasi atas peran dan posisi tuan guru sebagai pembentukpenentu wacana keagamaan di bagian ini secara khusus merujuk temuan penelitian penulis sendiri tentang persepsi gender tuan guru dan pengaruhnya bagi pembesaran wacana terkait di Lombok. Lihat lagi, "Membaca...," 1-24. 
mereka (berupaya) membentuk sekaligus mengontrol wacana dan kesadaran keagamaan masyarakat melalui, misalnya, institusi semi-negara yang belakangan amat rajin mengeluarkan fatwa ini itu, Majelis Ulama Indonesia (MUI). Sementara di wilayah "abuabu" (grey area), sebagian dari mereka memanfaatkan otoritas itu untuk melempangkan jalan merengkuh kekuasaan politik.

Sebagai pembentuk utama wacana keagamaan di Lombok, para tuan guru mengendalikan-mengontrol dinamika keagamaan masyarakat. Itu efektif mengingat, pertama, struktur mentalitasbudaya masyarakat umumnya masih tradisional-paternalistikfeodalistik sehingga peran dan posisi tuan guru sangatlah determinan, bahkan dominan, dalam proses-proses perubahan sosial di Lombok. Segala apa yang dilepas tuan guru ke tengah publik dengan segera menjadi pedoman berpikir dan berprilaku masyarakat. Maka, dapatlah diduga apa yang bakal mengharubiru benak dan prilaku masyarakat jika, misalnya, yang disorong para tuan guru ke ruang publik adalah wacana-wacana antipluralisme.

Lalu, kedua, efektivitas pembentukan wacana keagamaan dalam kesadaran masyarakat juga menjadi mungkin karena basis epistemologis wacana itu diproduksi dari keyakinan-keyakinan derivat ajaran agama. Dan, ketiga, upaya pembentukan wacana keagamaan juga kian efektif melalui proses transmisi pengetahuan keagamaan yang bersifat massif-intensif melalui praktik-praktik diskursif. ${ }^{14}$ Secara umum praktik-praktik dimaksud menunjuk pada berbagai proses transmisi kesadaran publik sebagaimana yang lazim mereka lakukan lewat aneka forum pembelajaran seperti pengajian umum, tabligh akbar, pengajaran di pesantren, dan juga $h \square$ alaqah, seminar-seminar.

${ }^{14}$ Term discursive-practice ini dipinjam dari Foucault. Dipakai untuk menjelaskan strategi kekuasaan (penguasaan) yang efektif dalam mendikte masyarakat untuk memikirkan mana yang dianggap penting dan tidak, mana yang dianggap benar dan yang musti dianggap salah, mana yang harus diteguhkan dan mana pula yang harus dirubuhkan. Dengan itu Foucault menegaskan bahwa cara pandang baru masyarakat yang mengubur cara pandang lama mustahil diperoleh tanpa rangkaian-rangkaian formasi pengetahuan yang bermain di wilayah inter-diskursif. Lihat Michel Foucault, The History of Sexuality: An Introduction, ter. Robert Hurley, vol. 1 (New York: Pantheon Books, 1978), 93. 
Dalam pada itu, melalui hubungan patron-client yang kental, para tuan guru menikmati cukup banyak "privilege sosial" yang, secara umum, termiliki lantaran kapasitas intelektual keagamaan atau latar sosial-ekonomi-politik mereka. ${ }^{15}$ Sistem sosial masyarakat Sasak yang dihadapi para tuan guru hari ini boleh jadi telah mengalami banyak pergeseran dan perubahan diferensiasi fungsional. Peran-peran mediasi sosial tuan guru kini mulai banyak diwakili (diambil-alih!) oleh beragam mediasi institusional yang marak bermunculan seiring dinamika cepat dunia modern. ${ }^{16}$ Namun toh tetap saja, dalam derajat tertentu, mereka masih memiliki sejumlah privilege sosial dan menikmatinya. Sebab, bagaimanapun, hingga saat ini secara de facto masyarakat Sasak Lombok masih menaruh kepercayaan besar kepada para tuan guru—saat mana social distrust terhadap negara justru terus menguat. Karena itu, kemungkinan mereka tetap memainkan peran sebagai aktor, katalisator, dan mediator bagi setiap perubahan sosial tetaplah besar. Secara normatif, kemampuan mereka untuk mendialogkan, mengakomodasi, dan mengkompromikan beragam pertentangan sosial dalam masyarakat tetap dibutuhkan.

Dengan "hak-hak istimewa" selaku elite agama itu, para tuan guru bahkan masih dapat memainkan peran sebagai "pressure group" dan "rulling class" pada level tertentu dalam struktur sosialpolitik masyarakat Sasak. ${ }^{17}$ Dalam banyak kasus, mereka tampak

15Tanpa adanya "keunggulan kompetitif" itu, secara politis, kehadiran eksistensial tuan guru dipastikan tidak legitimate di hadapan umatnya. Dalam masyarakat paternalistik, legitimasi (sosial) itu penting, menjadi syarat prakondisi bagi berhasil-tidaknya mereka dalam menjalankan peran sebagai makelar budaya atau sebagai agen perubahan sosial.

${ }^{16}$ Mediasi kelembagaan dimaksud adalah menjamurnya lembaga swadaya masyarakat (LSM; Non-Government Organization [NGO]) yang dengan modus eksistensialnya masing-masing relatif mampu memainkan peran sebagai penggerak dinamika sosial-budaya-politik di Lombok dan NTB secara keseluruhan. Sekedar menyebut, seperti LBH APIK, LeNSA NTB, Nusatenggara Center (NC), YPKM, dan lain-lain. Tentu, kemunculan mereka itu melahirkan stratifikasi sosial baru dan sekaligus, hingga tingkat tertentu, potensial memicu timbulnya konflik dan mempengaruhi proses integrasi sosial di Lombok.

17 Tentang peran sebagai pressure group dan rulling class ini lihat teoretisasinya pada M. Munandar Soelaiman, Dinamika Masyarakat Transisi: 
terlibat secara sangat menentukan di hampir setiap kegaduhan sosial-politik di Lombok. Tak aneh bila hampir setiap proses politik di pulau "seribu masjid" ini terkesan kurang legitimate tanpa menyertakan mereka dalam hiruk-pikuknya. Pada kasuskasus pemilihan kepala daerah, misalnya, nyaris tak pernah sepi dari kelebatan mereka, baik dalam menggiring opini maupun menggalang massa. ${ }^{18}$

Hal paling mendasar yang memperkuat otoritas para ulama, termasuk tuan guru, sebagai "pengendali" kesadaran (keagamaan) masyarakat adalah legitimasi mereka sebagai pemproduk "kebenaran". Berdasar legitimasinya itu, otoritas lalu dilihat sebagai hal yang given, suatu yang taken for granted. Ini tentu melahirkan pandangan bahwa segala tindak penafsiran, penghayatan, dan keberagamaan merupakan wilayah otoritas tunggal dari ulama atau lembaga-lembaga sosial-keagamaan di mana mereka berhimpun seperti MUI.

Di Lombok, sebagaimana umum pula di tempat-tempat lain, pandangan sedemikian itulah yang galib berjejalan dalam benakkesadaran publik. Orang merasa bahwa memang sudah seyogyanya otoritas untuk menentukan hitam-putih kesadaran keagamaan itu, secara teologis maupun sosial, "diberikan"

Mencari Alternatif Teori Sosiologi dan Arah Perubahan (Jogjakarta: Pustaka Pelajar, 1998), 148. Figur tuan guru sendiri sangat berpengaruh di kalangan etnis Sasak, dan karena etnis ini mayoritas tentu saja eksistensinya di area publik (sosial, politik, budaya, agama) amat determinan. Dalam konteks politik, misalnya, hingga tingkat tertentu mereka menjadi prime factor dinamika. Terlebih setelah M. Zainul Majdi, seorang tuan guru berpengaruh cucu tuan guru paling kharismatik di Lombok, Mawlana Syekh TGH Zainuddin Abdul Madjid, terpilih sebagai gubernur NTB baru lalu, tentu kian memperkuat posisi tawar institusi tuan guru dalam lanskap sosialkultural-politik Lombok.

${ }^{18}$ Trend ini mulai menguat terutama sejak sejumlah tuan guru terlibat aktif di area politik, di legislatif maupun eksekutif. Tunjuk misal TGH Taqiyuddin Mansyur atau TGH Hamid Faishal di dewan dan TGH M. Zainul Majdi yang baru terpilih sebagai gubernur NTB, atau TGH Muharror, seorang anggota dewan, yang pernah mencoba peruntungan dan sempat memantik kehebohan menyusul kegagalan pencalonannya di pilkada Lombok Barat tempo hari. Ada pula TGH Hasanain Juwaini yang aktif sebagai ketua KPU Lombok Barat dan TGH Mahally Fikri yang memegangi jabatan ketua KPU NTB. 
kepada tuan guru selaku ulama atau kelembagaan-kelembagaan sosial-keagamaan semi-negara seperti MUI. Mereka pun tampil sebagai institusi-institusi yang memiliki otoritas absolut untuk menentukan cetak-biru kesadaran publik dalam beragama dan, bahkan, berpolitik. Akibatnya, dalam konteks keberagamaan, segenap hasil penafsiran atau bentuk penghayatan keagamaan di luar apa yang mereka produk serta-merta dianggap sebagai bentuk penyimpangan dus penistaan atas agama. Segala bentuk keberagamaan yang dianggap menyebal dari keyakinan mainstream yang galib mereka wakili akan seketika dilabeli "sesat" dan karena itu harus segera diinsyafkan dengan mengembalikan para pelaku ke keyakinan "resmi".

Penggunaan otoritas secara demikian dalam suatu masyarakat yang masih bermental feodalistik, mendekap paternalisme, dan merawat pola hubungan patron-client seperti di Lombok jelas bukan tanpa efek sama sekali. Justru efeknya bisa sangat serius! Suatu rezim kebenaran yang diproduk dan/atau diteguhkan oleh ulama, atau apalagi bila dikukuhkan melalui kelembagaan "resmi" seperti MUI, acap kali menjadi alasan pembenar bagi masyarakat untuk, misalnya, bergerak mengancam, menyerang, membakar, dan menindas kelompok atau orang-orang berkeagamaan atau berkeyakinan beda atas nama kebenara versi "resmi" atau mayoritas. ${ }^{19}$ Sejumlah kasus mutakhir di Lombok, misalnya yang menimpa Jemaat Ahmadiyah, kaum Syi'ah, dan komunitas Salafi, membuktikan dugaan itu. ${ }^{20} \mathrm{Di}$ tengah situasi

19 Pada tahun 2008, kasus pelanggaran kebebasan beragama dan berkeyakinan berlangsung cukup tinggi, sekitar 234 kasus. Artinya setiap bulan (antara Januari-November) minimal terjadi 16 kasus baik yang melibatkan negara maupun antarwarga sendiri. Ada kecenderungan meningkat ketimbang tahun-tahun sebelumnya. Intensitas kasus dan spektrum isu meluas tidak lagi semata-mata berkait dengan isu kebebasan beragama dan berkeyakinan tapi isu-isu keagamaan secara umum. Data merujuk Laporan Tahunan The WAHID Institute tentang Pluralisme Beragama dan Berkeyakinan di Indonesia Tahun 2008 berjudul "Menapaki Bangsa yang Kian Retak" dalam situs http://www.wahidinstitute. org/files/_docs/Laporan \%20Pluralisme\%202008\%20WahidInstitute.pdf, diakses Rabu, 7 Januari 2008, 10.24 WIB.

${ }^{20}$ Bila dirunut, kasus kekerasan atas Ahmadiyah hanyalah ekses lanjut dari fatwa "penyesatan" yang diinstitusionalisasi ulama, terutama yang berhimpun diri dalam lembaga keagamaan bentukan pemerintah (dan 
sosial-keagamaan itu tentu reasonable bila banyak kalangan melihatnya sebagai ancaman serius bagi praksis kebebasan beragama di sana.

Lalu, apa yang dimaksud dengan "kebebasan beragama" sendiri? Pertanyaan ini penting mengingat ajuan definisi kebebasan beragama memang begitu beragam dan variatif terutama pada teknik operatif bagaimana isu tersebut sebagai hak hendak diperjuangkan atau diatur atau dipraktikkan. Oleh sebab itu perspektif kebebasan beragama yang dihela sebagai rangka pemaknaan di tulisan ini disusun secara eklektik. Amat banyak makna operasional tentangnya. Namun, dari sekian ragam definisi itu tetap saja senafas dalam satu hal, yakni pengenaan spirit kebebasan yang apresiatif terhadap pemenuhan hak bagi setiap individu untuk beragama — termasuk untuk tidak beragama sekalipun. Hak beragama mengandung pengertian tak hanya hak memilih agama anutan, tapi juga hak untuk bebasmandiri memahami atau memaknai atau menafsirkan agama anutan, sekaligus hak bebas mengekspresikan ajaran agama atau keyakinan itu. ${ }^{21}$ Maka, penghadiran spirit toleransi dalam setiap praktik keberagamaan yang berbeda-beda menjadi satu hal niscaya selain menjadi kewajiban negara dalam pemenuhannya. ${ }^{22}$

karenanya politis!), MUI. Sejak Munas II tahun 1980, MUI sudah memvonis Ahmadiyah sebagai murtad, kafir, dan sesat-menyesatkan. Kasus penyerbuan itu menegaskan fakta betapa fatwa "pemurtadan" itu efektif memantik atau memperluas eskalasi kekerasan.

${ }^{21}$ Satu definisi, misalnya, mengartikan kebebasan beragama sebagai suatu notion that people of religion can freely partake of the practices of their religion without opposition; this would not only include private devotions, but also acts of religious significance within the realm of government. Lihat "What is Religious Freedom?" dalam http://www.mindspring.com/ careyb/rf_defn.html, diakses Rabu, 22 Oktober 2008, 11.54 WIB. Lihat juga definisi Franklin I. Gamwell, The Meaning of Religious Freedom: Modern Politics and the Democratic Resolution (Albany, New York: State University of New York Press, 1995), 10. Hanya saja ia banyak menekankannya dalam konteks politik dan demokrasi. Ia gunakan untuk mengidentifikasi prinsip-prinsip politik yang mengakui bahwa pluralitas keberagamaan internal yang legitimate sejatinya merupakan bukti unitas dari berbagai bentuk keberagamaan itu sendiri.

${ }^{22}$ Di Indonesia, kebebasan beragama sebagai sebuah hak asasi manusia sejatinya telah diakomodasi terutama di pasal 29 UUD 1945, UU No. 39/1999 tentang HAM, dan UU No. 12/2005 tentang Ratifikasi Kovenan 
Ajuan pengertian dan penghadiran spirit toleransi dalam ide kebebasan beragama serta pewajiban negara untuk memenuhinya didasarkan pada norma-norma kebebasan beragam itu sendiri. Terdapat setidaknya delapan norma kebebasan beragama, yakni (1) kebebasan internal; (2) kebebasan eksternal; (3) tanpa diskriminasi; (4) tanpa paksaan; kebebasan berkumpul dan memperoleh status hukum; (6) pembatasan kebebasan eksternal yang diperkenankan; (7) hakhak orangtua dan wali; dan norma (8) non-derogabilitas. ${ }^{23}$ Kedelapan norma yang mengerangkai hak asasi manusia (HAM) dalam beragama (religion) dan berkeyakinan (belief) itu disarikan dari dua instrumen HAM internasional, yakni Universal Declaration of Human Rights (Deklarasi Universal tentang Hak Asasi Manusia) ${ }^{24}$ dan International Covenant on Civil and Political

Internasional mengenai Hak-hak Sipil dan Politik. Hanya saja, negara masih cenderung inkonsisten dalam mengapresiasinya. Ini terkait fakta masih adanya sejumlah aturan derivat yang diametral berpunggungan, seperti "masih berlakunya" Surat Edaran Menteri Dalam Negeri No. 477/74054/BA.01.2/4683/95 tertanggal 18 Nopember 1978 yang cuma mengakui lima agama "resmi" (Islam, Katolik, Protestan, Hindu, dan Buddha). Terlebih jika mencermati fakta-fakta pelanggaran kebebasan beragama yang belakangan kian marak di mana negara justru cenderung "membiarkan". Pemerian lanjut berbagai regulasi diskriminatif dan inkonsistensi negara ini lihat selengkapnya Asri Oktavianty Wahono, dkk., Reformasi Hukum terhadap Kebijakan Diskriminasi Ras dan Etnis di Indonesia (Jakarta: Solidaritas Nusa Bangsa - The Asia Foundation, 2003). Bdk. Fawaizul Umam, "Menakar Kebebasan Beragama di Indonesia: Rekonstruksi Peran Negara, Revitalisasi Inklusivitas Beragama” - Makalah, disampaikan pada Annual Conference on Islamic Studies 2007 (21-24 November 2007) Direktorat Pendidikan Tinggi Islam Dirjen Pendidikan Islam Depag RI di Pekanbaru Riau - Jumat, 23 November 2007: 1-17.

23Lihat Tore Lindholm, W. Cole Durham, Jr., Bahia G. Tahzib-Lie, dan Nazila Ghanea, "Introduction," dalam Tore Lindholm, W. Cole Durham, Jr., dan Bahia G. Tahzib-Lie (eds.), Facilitating Freedom of Religion or Belief: $A$ Deskbook (Leiden, The Netherlands: Koninklijke Brill NV, 2004), xxxvii-ix.

${ }^{24}$ Universal Declaration of Human Rights (UDHR) ini terdiri dari 30 pasal. Dideklarasikan dan diadopsi Majelis Umum PBB (United Nations General Assembly) sebagai resolusi PBB no. 217 A (III) pada 10 Desember 1948. Lihat "Universal Declaration of Human Rights" dalam http://www.un.org/Overview/rights.html, diakses Rabu, 22 Oktober 2008, 10.56 WIB. 
Rights (Kovenan Internasional tentang Hak-hak Sipil dan Politik) ${ }^{25}$ yang telah diratifikasi PBB (UNO/United Nations Organization).

Ide kebebasan beragama sedemikian itulah yang menurut penulis telah tercederai dan potensial terus terancam oleh logika keagamaan dan pemanfaatan otoritas para ulama. Simpulan ini dapat dirunut dari bagaimana logika keagamaan dan penggunaan otoritas sosial-kultur-keagamaan itu mewujud di level refleksi teologis sekaligus aksi praktis mereka sendiri.

\section{Paradigma Eksklusif}

Refleksi teologis menunjuk pada paradigma ${ }^{26}$ dakwah yang selama ini dikembangkan para tuan guru. Seperti kebanyakan ulama, para tuan guru umumnya menjalankan aktivitas dakwah sebagai muballigh atau dầi. Bahkan, aktivitas ini merupakan bagian inheren dari manifestasi peran profetik mereka secara keseluruhan.

Dalam perspektif pluralisme, pola dakwah tuan guru, secara paradigmatik cenderung berpunggungan dengan discourse pluralisme. Tendensi antipluralisme itu umumnya menampak pada aktivitas dakwah yang mereka jalankan. Secara paradigmatik, hal itu menegas kuat pada kehendak "memperbanyak" umat di kesadaran teologis para tuan guru

${ }^{25}$ Perjanjian (covenant) internasional yang terdiri dari 53 pasal ini disusun dan diratifikasi melalui Majelis Umum PBB. Pakta yang penyusunannya didasarkan pada UDHR ini dibuat pada 16 Desember 1966 dan kemudian ditetapkan sebagai resolusi PBB No. 2200 A (XXI) pada 23 Maret 1976. Lihat "International Covenant on Civil and Political Rights" dalam situs http://en.wikisource.org/wiki/International_Covenant_on_Civil_and_Polit ical_Rights, diakses pada Rabu, 22 Oktober 2008, 11.31 WIB.

${ }^{26}$ Maksud paradigma (paradigm) di sini ialah konstelasi teori, pendekatan, dan prosedur yang digunakan oleh suatu nilai atau tema pemikiran. Ia dikembangkan dalam rangka memahami kondisi sejarah dan situasi sosial untuk memberi kerangka konsepsi dalam memaknai realitas. Kekuatan suatu paradigma terletak pada kemampuannya membentuk apa yang dilihat, bagaimana cara melihat, apa yang dianggap masalah, apa masalah yang bermanfaat untuk dipecahkan, dan apa metode yang sepatutnya dipakai dalam meneliti dan berbuat. Selengkapnya, untuk ulasan seputar paradigma, lihat Thomas Kuhn, The Structures of Scientific Revolution (Chicago: the University of Chicago Press, 1970). 
(dầ $)$ — tidak hanya sekedar berorientasi "membina" umat, suatu upaya penguatan ke dalam. ${ }^{27}$ Simpulan ini disandarkan pada hasil pengarifan kritis atas dua aspek dari pola dakwah itu sendiri, yakni teknis dan substantif. ${ }^{28}$ Aspek teknis menunjuk pada (1) strategi, (2) metode, (3) materi, dan (4) model forum, sedang aspek substantif menegas di rumusan teologis tuan guru tentang (1) pengertian dakwah, (2) motivasi yang mengalasi aktivitas mereka, dan (3) tujuan atau target dari dakwah yang mereka lakukan.

Dari sisi teknis, pola dakwah yang dikembangkan tuan guru umumnya berpola konvensional baik dari segi strategi, metode, forum yang lazim digunakan, dan materi yang biasa disampaikan. Secara umum berstrategi persuasif, ${ }^{29}$ metode oral (bi al-lisân) monologis, materi yang kelewat "teosentris", dan ditransmisikan

27 Tipefikasi paradigma dakwah ini disandarkan pada lima trend penghayatan dan ekspresi religius yang diandaikan mendasari tipologi dakwah tuan guru, yakni eksklusivisme, inklusivisme, paralelisme, pluralisme, dan partikularisme. Lihat lebih lanjut pemeriannya pada dua sumber: tiga trend pertama pada Raimundo Panikkar, Dialog Intrareligius, ter. J. Dwi Helly Purnomo dan P. Puspobinatmo (Jogjakarta: Kanisius, 1994), 18-24; dan dua trend terakhir pada Terrence W. Tilley, Postmodern Theologies and Religious Diversity (Maryknoll, New York: Orbis Book, 1996), 158.

${ }^{28}$ Identifikasi ini secara khusus bersandarkan hasil penelitian penulis, Antara Membina dan Memperbanyak Umat: Pola Penyiaran Agama Hindu dan Islam di Kota Mataram, Laporan Penelitian (Mataram: P3M STAIN Mataram, 2004). Fokus studi dari penelitian komparatif ini diarahkan pada penyisiran tendensi pluralisme dan/atau antipluralisme dalam paradigma penyiaran Islam (da'wab) dan Hindu (dharma; dharma wacana) sebagaimana dikembangkan para pegiatnya (Islam, da'i: Hindu, dharma duta).

${ }^{29}$ Tipefikasi ini berpijak pada dua model strategi penyiaran agama, yakni pertama, strategi persuasif (persuasive strategy) untuk membentuk opini masyarakat dengan cara lisan maupun tulisan, yang dalam perspektif komunikasi massa tak beda jauh dengan propaganda; dan kedua, strategi normatif-reedukatif (normative-reeducative strategy) di mana segenap norma sosial dipahami sebagai hasil elaboratif dari ajaran agama yang termasyarakatkan lewat pendidikan. Karena itu, strategi ini lazim disandingkan dengan upaya pendidikan-ulang (reeducating) untuk mengganti norma dan paradigma berpikir masyarakat dari yang lama ke yang baru. Dihimpun dan dielaborasi lebih lanjut dari ajuan beberapa sumber, seperti J.A.C. Brown, "Propaganda and Communications," dalam Creating Social Change, 360-70; dan Torgny T. Segerstedt, The Nature of Social Reality (Stockholm: Svenska Bokforlaget, 1966), 105. 
ke khalayak melalui forum-forum rutin seperti pengajian dan khutbah Jumat. Dengan mendudukkan mereka sebagai pusat transmisi pengetahuan, nyaris tak ada pengayaan kritis atas ajaran melalui tipologi dakwah sedemikian. Praktis, pikiran keagamaan tuan guru yang ditransmisikan melalui aktivitas dakwah menjadi cetak-biru epistemologis dari wacana keagamaan umat.

Sementara dari aspek substantif, tuan guru umumnya menghela pola dakwah yang secara paradigmatik cenderung bertipe eksklusif. Anasirnya dapat dijumpai pada refleksi teologis mereka sendiri terhadap apa itu dakwah, motivasi mereka melakukannya, dan target-tujuan dari aktivitas itu. Tipe eksklusif menegaskan pandangan-sikap yang mengklaim bahwa keselamatan atau kebenaran hanya ada pada agama anutan. ${ }^{30} \mathrm{Hal}$ itu terutama menampak di formulasi tujuan dakwah mereka yang tak cuma berupaya "mengislamkan" umat Islam tapi juga umat non-Muslim. Tak heran, bila dakwah tak hanya dimaknai sebagai "penyiaran", tetapi juga "penyebaran" agama. 31

Dengan demikian eksklusivisme dakwah mereka berlawanan diametral dengan paradigma pluralistik (pluralisme) yang bertumpu pada keyakinan bahwa terdapat begitu banyak 'jalan' (agama) menuju Yang Satu. ${ }^{32}$ Bila dakwah dikerangkai dengan paradigma pluralistik ini tentulah dakwah tidak mungkin

${ }^{30}$ Makna eksklusif atau eksklusivisme di sini merujuk Panikkar, Dialog..., 18-24.

${ }^{31}$ Pandangan-sikap sedemikian cenderung mendominasi benak-pikir para tuan guru. Namun, bukan berarti anasir inklusivisme tak ada sama sekali. Hingga level tertentu, nilai-nilai inklusif turut pula mewarnai paradigma penyiaran satu-dua dä. Tipe inklusif juga kuat memegangi klaim "kebenaran tunggal", cuma lebih "santun". Islam tetap diyakini punya kebenaran yang lebih sempurna daripada agama lain. Agama lain boleh jadi benar asalkan kebenaran dan keselamatan yang diusungnya memiliki sejumlah kriteria sebagaimana yang dimiliki Islam. Jadi, menghadirkan Islam kurang-lebih sebagai tolok ukur kebenaran bagi agama lain. Tentang makna operasional inklusif atau inklusivisme lihat ibid.

${ }^{32}$ Untuk pengertian pluralisme lihat Tilley, Postmodern..., 158; Juga John Hick, "Religious Pluralism", The Encyclopedia of Religion, V, ed. Mircea Eliade (New York: Simon \& Schuster Macmillan, 1995), 331; dan Diana L. Eck, $A$ New Religious America: How a "Christian Country" Has Become the World's Most Religiously Diverse Nation (New York: Harper San Francisco, 2001), 70-1. 
dilaksanakan dengan makna "penyebaran", melainkan semata "penyiaran" dengan tujuan yang lebih berorientasi "ke dalam", memperkuat keberagamaan umat. Sebab, paradigma ini beranggapan bahwa setiap agama sama-sama baik, sama-sama menyimpan kebenaran betapapun berbeda corak substansinya. Maka, sikap terbaik dalam berdakwah, menurut paradigma ini, adalah mengapresiasi klaim-klaim teologis lain. Dan sikap yang memastikan agama mana yang benar dan selamat seraya menegasikan yang lain adalah tindakan pongah karena berarti sok tahu tentang bagaimana Tuhan pada akhirnya memperlakukan segala sesuatu. ${ }^{33}$

Merujuk tiga fenomena prilaku keberagamaan kontemporer (fundamentalisme, relativisme, dan rasionalisme), ${ }^{34}$ paradigma dakwah yang cenderung eksklusif itu berpotensi mendorong eskalasi fenomena fundamentalisme Islam di Lombok, suatu prilaku keberagamaan yang semata-mata bersandarkan keyakinan bahwa kebenaran (Islam) itu unique dan hanya berada di pihaknya.

Lalu, apakah pola dakwah yang secara paradigmatik cenderung eksklusif dan potensial menyuburkan fundamentalisme itu merupakan refleksi langsung dari ajaran Islam? Ataukah, jangan-jangan, hanya semacam refleksi belaka dari konsekuensi logis relasi mayoritas-minoritas antarumat beragama atau antarkelompok di kalangan umat Islam? Jika yang terakhir yang betul, tentu ironis. Sebab, itu berarti para pegiat dakwah itu sebenarnya mengidap "penyakit" klise: arogansi spiritual sekaligus sosial karena diri mayoritas. Realitas tersebut secara umum cukup untuk menyimpulkan bahwa model dakwah berparadigma eksklusif dan bertendensi fundamentalis jelas sangat berpotensi memicu disintegrasi, benturan antarumat.

Simpulan itu tak berlebihan. Sejumlah penelitian menegaskanya. Ambil misal penelitian Suprapto. ${ }^{35}$ Dengan

${ }^{33}$ Ibid.

${ }^{34}$ Makna tiga fenomena prilaku keberagamaan ini merujuk Ernest Gellner, Postmodernism, Reason, and Religion (London: Routledge, 1993), viii.

35Penelitian yang dilakukan tahun 2004 dan difasilitasi oleh Lemlit IAIN Mataram itu berjudul Dakwah Islamiyah dalam Perspektif Pluralisme Agama (Analisis Isi Khutbah Jumat pada Masjid-masjid di Kota Mataram). Versi artikel 
prasangka pluralisme, ia berikhtiar menyoal persepsi teologis para pelaku dakwah terkait wacana pluralisme sebagaimana mereka ceramahkan rutin dalam forum shalat Jumat. Dengan menerapkan analisis isi (content analysis) atas materi khutbah Jumat pada sejumlah masjid di kota Mataram yang disampaikan para khâthib yang kebanyakan terbilang tuan guru, ia bermaksud menakar sejauh mana mereka mengapresiasi dan mengafirmasi wacana pluralisme agama (religious pluralism) sekaligus menyisir adakah tendensi antipluralisme dalam materi khutbah mereka. Dan, seperti diduga, ia tiba pada simpulan betapa rendah perhatian para khät ib terhadap wacana pluralisme, sebagian bahkan menyembulkan kecenderungan antipluralisme dalam materi khutbah mereka.

Pemanfaatan forum model konvensional semisal khut $\square$ bah Jumat dan pengajian umum yang monologis itu jelas efektif membentuk wacana keagamaan masyarakat Lombok yang Indeks Pembangunan manusia (IPM)-nya disebut-sebut terbilang rendah dari seluruh provinsi di Indonesia. Dengan forum transmisi pengetahuan yang monologis itu dan posisi tuan guru yang secara teologis maupun sosial berada di puncak piramida "stratifikasi" kehidupan sosial, segala apa yang dilansir tuan guru diterima umat nyaris tanpa reserve kritis, relative tak terbantah. Akibatnya, apa saja yang digelontorkan tuan guru seketika disambut umat dan dalam banyak hal efektif mempengaruhi cara mereka dalam beragama dan menyikapi kenyataan-termasuk kenyataan seputar praksis kebebasan beragama.

Soal efektivitas pengaruh tuan guru dalam membentuk pengetahuan keagamaan masyarakat itu dapat dijumpai dalam sejumlah penelitian. Beberapa penelitian berhasil membuktikan ada korelasi positif dakwah tuan guru dengan konstruk paradigmatik keyakinan teologis dan pemahaman keagamaan masyarakat. Taruh misal penelitian Mustain di tahun 2003.36

dengan judul serupa dimuat di Jurnal Tasamuh, vol. 2, no. 1 (Desember, 2004), 61-78.

${ }^{36}$ Studi kancah yang mengambil kota Mataram sebagai lokasi penelitian itu berjudul Hubungan Hindu-Muslim di Kota Mataram (Kajian terhadap Potensi 
Penelitiannya tidak hanya menggambarkan realitas hubungan antarumat beragama, tapi juga menelusuri potensi konflik yang mengintai latent dalam setiap pola hubungan antaragama. Dalam kerangka itu ia mengkomparasikan pandangan teologis dan prilaku keagamaan antardua umat beragama, Hindu dan Muslim. Penyisiran atas kedua umat mengantar Mustain pada simpulan bahwa secara teologis kaum Muslim menyimpan "masalah" dalam membangun hubungan yang toleran dengan umat lain dan karena itu potensi konflik relatif lebih mengendap di sini; sebaliknya, potensi integratif di ranah sosial-budaya justru lebih menguat di kalangan umat Hindu. Tentu saja, bila tesis Mustain tersebut benar, itu akan menjadi kenyataan ironis bagi Islam yang secara teologis mengklaim kehadirannya sebagai rabmatan lil-álamin. Menariknya, Mustain juga berhasil melihat hubungan korelatif pandangan para informan Muslim dengan refleksi teologis tuan guru seputar hubungan antaragama. Mengutip Mustain, pengetahuan mereka itu terbentuk dari sejarah panjang proses pembentukan pengetahuan oleh tuan guru sebagai institusi keagamaan paling berpengaruh di Lombok.

Di titik itulah kita dapat meletupkan kecemasan ilmiah betapa serius ancaman pola dakwah tuan guru yang secara paradigmatik eksklusif itu bagi hubungan antarumat beragama, dan itu artinya juga bagi praksis kebebasan beragama, di Lombok pada saat kini dan masa-masa mendatang. Sejumlah kasus yang beberapa di antaranya diungkap berikut memperkuat tengara itu!

\section{Memantik Kekerasan}

Di ranah sosial, pengejawantahan dari paradigma dakwah yang eksklusif dan mempromosikan eksklusivitas plus fundamentalisme keberagamaan itu dalam banyak hal telah memantik sejumlah kekerasan, fisik maupun intelektual. Setidaknya terdapat lima bentuk kekerasan atas nama agama yang menggambarkan trend faktual tercederainya spirit dan praksis kebebasan beragama selama ini di Lombok.

Konflik dan Integrasi Hubungan Antaragama), Laporan Penelitian (Mataram: P3M STAIN Mataram, 2003). 
Pertama, "peminggiran" sistematis atas nama da'wah islâmiyah terhadap aneka bentuk keberagamaan lokal. Salah satu kelompok keagamaan lokal yang tak kunjung henti hingga kini mengalami penetrasi dakwah tuan guru adalah komunitas Islam Wetu Telu. ${ }^{37}$ Gencarnya penetrasi dakwah beraura eksklusif yang memaksakan versi Islam "sejati" itu sebenarnya telah diretas sejak awal abad ke-20 seiring bangkitnya pengaruh tuan guru di saat pengaruh kultural bangsawan Sasak mulai menyusut. ${ }^{38}$

Melalui dakwah tersebut, kaum Wetu Telu mengalami dua lapis kekerasan sekaligus, yakni (1) kekerasan teologis yang beriringan dengan (2) kekerasan sosial. Kekerasan teologis yang menerpa berupa stigmatisasi atas keyakinan mereka sebagai sebentuk Islam sinkretik, animis, heterodoks, yang notabene sesat dan menyesatkan dan karena itu perlu "diinsyafkan". Dilancarkan sistematis oleh sejumlah tuan guru guna mengkonversi mereka dari keyakinan tradisional Wetu Telu ke model keislaman ala Waktu Lima yang lebih ortodoks, "murni", dan tentu saja paling "benar". ${ }^{39}$ Sementara kekerasan sosial

${ }^{37}$ Fakta-fakta seputar penetrasi dakwah tuan guru ini lihat Fawaizul Umam, dkk., Membangun Resistensi, Merawat Tradisi: Modal Sosial Komunitas Wetu Telu (Mataram: LKIM IAIN Mataram, 2006). Bdk. dengan Leena Marjatta Avonius, Reforming Wetu Telu: Islam, Adat, and the Promises of Religionalism in Post-New Order Lombok, Ph.D Dissertation (Universiteit Leiden, 2001). Sejumlah fakta terkait juga diajukan Budiwanti, Islam Sasak..., 285-341. Namun, tesis Budiwanti cenderung bias "Waktu Lima"; ia mengapresiasi aktivitas dakwah dan melihatnya justru sebagai cara "menyelamatkan" mereka dari keterbelakangan hidup dan ketersesatan dalam bertuhan.

${ }^{38}$ Ibid., 290-311.

${ }^{39}$ Anggapan ini dibantah Budiwanti dengan menyebut bahwa aktivitas dakwah di kawasan budaya Wetu Telu (Bayan, Lombok Barat) tidak dimaksudkan untuk mengubah keagamaan orang Bayan asli, melainkan untuk menjaga jati diri para transmigran Muslim Waktu Lima di tengah komunitas Wetu Telu. Lihat ibid., 122. Namun fakta-fakta ternyata menunjukkan sebaliknya, justru membenarkan tuduhan bahwa dakwah memang dilangsungkan dengan niat untuk mengkonversi mereka ke model Islam Waktu Lima. Lihat fakat-fakta temuan Umam, Membangun Resistensi...,103-15; Bdk. juga dengan tesis dan fakta serupa dari Sven Cederroth, The Spell of the Ancestors and the Power of Mekkah: A Sasak Community on Lombok (Gọ̈teborg, Sweden: ACTA Universitatis Gothoburgensis, 1981). 
berlangsung terutama dalam bentuk diskriminasi sosial-politik, langsung maupun tidak, oleh pemerintah (lokal; pemkab Lombok Barat dan Lombok Timur). Berupa sejumlah kebijakan politik lokal diskriminatif seperti penguatan aturan "lima agama resmi", penataran wajib bagi para kiai Wetu Telu berdasar rekomendasi tuan guru, dan proyek transmigrasi lokal yang kian melemahkan otoritas adat Wetu Telu atas kawasan budayanya di Bayan. ${ }^{40}$

Konsekuensi lanjut dari dua lapis kekerasan atas kaum Wetu Telu itu sungguh mengenaskan. Seiring perkembangan zaman, semakin hari mereka semakin terpinggirkan dari dinamika sosial masyarakat Lombok secara keseluruhan. Mereka yang tersisa kini semakin terpencil dari komunitas besar etnis Sasak dan terstigma sebagai segmen masyarakat yang old fashioned, tertinggal jaman. Signifikansi kultural mereka kian memudar di hampir seluruh kawasan Lombok, kecuali di beberapa tempat, terutama di Bayan, sebuah kecamatan di kabupaten Lombok Barat NTB. ${ }^{41}$

Kedua, kekerasan atas Jemaat Ahmadiyah. Harus diakui Lombok memang bukan tempat yang nyaman dan ramah bagi warga Ahmadiyah. Di Lombok Timur, misalnya, massa dengan beringas membakari pemukiman Ahmadiyah pada 10-13 September 2002 dan membuat ratusan orang pengagum Mirza Ghulam Ahmad itu kehilangan tempat tinggal. Kediaman warga Ahmadiyah kembali diserbu di Praya Lombok Tengah pada Jumat, 17 Maret 2006, dan membuat mereka mengungsi ke Mapolres setempat. Sebulan sebelumnya, tepatnya 4 Februari 2006, kasus serupa menimpa mereka di Lingsar Lombok Barat hingga memaksa mereka kehilangan tempat tinggal dan mengungsi di asrama Transito Mejeluk Mataram hingga kini. ${ }^{42}$

${ }^{40}$ Lihat fakta-fakta terkait di Umam, Membangun Resistensi..., 115-32.

${ }^{41}$ Ibid., 2-3.

${ }^{42}$ Lihat unduhan 18 Desember 2008, 11.21 WIB berjudul "Warga Serang Anggota Ahmadiyah Lombok Timur" dalam http://m.infoanda.com/readnewstech.php; Lihat juga berita berjudul "Jemaat Ahmadiyah Sulit Kembali ke Kampungnya," dalam http://www.antara.co.id/arc/2008/6/12/jemaat-ahmadiyah-sulit-kembalike-kampungnya/, diakses 18 Desember 2008, 11.31 WIB. 
Sebagaimana di tempat-tempat lain, kekerasan atas Ahmadiyah di Lombok umumnya bertolak dari prasangka teologis bahwa ajaran Ahmadiyah "sesat" dan "menyesatkan". Eskalasinya berkait rekat dengan fatwa MUI dan ketidaktegasan pemerintah dalam menegakkan hukum (law enforcement). Tatkala pemerintah yang diharap mengunci ruang gerak Ahmadiyah tak jua tegas bersikap, mereka pun merasa menemukan momentum untuk mengambil logika penyelesaian sendiri: kekerasan. Tak pelak, seluruh tindak kekerasan itu seolah mendapat legitimasi teologis dan politis sekaligus. Umat lalu terbiasa memandang bahwa semua kekerasan itu cuma konsekuensi logis dari apa yang dalam nomenklatur Islam disebut $d a^{\prime} w a h$ islâmiyah.

Sejauh ini penulis memang belum menemukan bukti faktual keterlibatan langsung tuan guru dalam memobilisasi massa atau memerintahkan penghancuran kediaman warga Ahmadiyah. ${ }^{43}$ Namun, dapat dipastikan eskalasi kekerasan itu berkait rekat dengan "fatwa-fatwa" sporadik yang gencar mereka lansir ke ruang publik menyusul fatwa penyesatan dari MUI Pusat. Lewat fatwa itu (sementara) tuan guru amat aktif "meneror" kaum Ahmadiyah. Ketua MUI Lombok Barat TGH Mahally Fikri, misalnya, berujar "Aliran Ahmadiyah hingga kini belum bisa diterima oleh masyarakat Lombok sebab ajarannya menyimpang dari ajaran Islam." 44

Dalam kesempatan lain, para tuan guru yang berhimpun di MUI NTB terang-terangan mendesak Gubernur Nusa Tenggara Barat, Lalu Serinata, untuk segera mengeluarkan keputusan larangan terhadap kegiatan Ahmadiyah. Alasannya, mayoritas ulama di Indonesia sudah menyatakan ajaran aliran ini sesat dan

${ }^{43}$ Namun, dalam satu kasus penyerangan terhadap warga Ahmadiyah di Ketapang Gegerung kabupaten Lombok Barat, seorang tuan guru disebutsebut terlibat langsung memprovokasi dengan bertindak menyerukan atau menganjurkan penyerangan. Demikian laporan hasil penelusuran tim Komisi Nasional (Komnas) Hak-hak Asasi Manusia (HAM) sebagaimana dimuat dalamwww.komnasham.go.id/portal/files/laporan $\% 20$ kajian $\% 20$ ahmadiyah .pdf. diakses 18 Desember 2008, 14.09 WIB.

${ }^{44}$ Lihat "Ajaran Ahmadiyah Belum Dapat Diterima di Lombok," dalam situs http://www.kompas.com/utama/news/0602/07/075627.htm, diakses 18 Desember 2008, 14.52 WIB. 
menyimpang dari ajaran Islam. 45 "Sudah tidak ada waktu lagi berdialog dengan pengikut Ahmadiyah," kata Ketua Majelis Ulama Indonesia NTB Saiful Muslim di satu kesempatan. Jika pengikut Ahmadiyah tidak mau kembali ke ajaran Islam, Saiful meminta mereka membuat agama baru di luar Islam. ${ }^{46}$

Ujaran-ujaran seperti itu jelas potensial membakar masyarakat untuk bergerak menyerbu. Mungkin tak berkait kausal langsung, tetapi adalah fakta bahwa eskalasi kekerasan meningkat segera setalah fatwa "penyesatan" dilempar MUI ke publik. Namun, uniknya, MUI menolak kemungkinan adanya kaitan kekerasan massif atas Ahamdiyah itu dengan fatwa mereka. Mereka cenderung berlepas tangan dengan menuduh sesat Ahmadiyah seraya menolak aksi kekerasan atasnya sebagaimana dimaklumkan Din Syamsuddin, ketua umum PP Muhammadiyah sekaligus sekjen MUI, dan KH. Ma'ruf Amin, ketua komisi fatwa MUI. Tentu saja, itu kontradiktif. Menyatakan sesat tapi melarang kekerasan atas pihak yang di"sesat"-kan sungguh sikap ambigu. Sebab, bagaimanapun, secara teologis fatwa itu kian meneguhkan ghirah masyarakat untuk meledak.

Celakanya, pemerintah sendiri tampaknya lebih suka mengikuti irama gendang yang dimainkan sementara ulama ketimbang menegakkan konstitusi. Di Lombok, tak kurang wali kota Mataram, Ruslan, menerbitkan sebuah surat keputusan (SK) yang membatasi gerak Ahmadiyah. Juga Bupati Lombok Timur, H.M. Sukiman Azmy, segera setelah terpilih sebagai bupati baru, mempermaklumkan tegas bahwa tidak ada tempat lagi bagi Jemaat Ahmadiyah di Lombok, khususnya di kabupaten Lombok Timur. "Tapi kalau ada saudara kita (warga Ahmadiyah) yang ingin kembali ke ajaran Islam yang sebenarnya, kita terima dengan senang hati," tandasnya saat memberi arahan

45 Desakan itu sendiri merupakan hasil pertemuan para pemimpin organisasi keagamaan seperti NU, Muhammadiyah, Nahdlatul Wathan, dan pengasuh pesantren di seluruh NTB. Pertemuan di Masjid Raya At-Taqwa Mataram pada 17 April 2007 itu turut dihadiri para pejabat pemerintah Provinsi NTB. Lihat "Ulama NTB Desak Ahmadiyah Dilarang," dalam http://www.tempointeraktif.com/hg/nusa/2007/04/18/brk,2007041898282,id.html, diakses pada 18 Desember 2008, 12.19 WIB.

46 Ibid. 
pada Mudzakarah Alim Ulama di aula Kandepag Lombok Timur, 13 September 2008. ${ }^{47}$

Ketiga, penolakan atas pembangunan Pura Hindu Sangkareang di Keru Lombok Barat. Penolakan itu diikuti dengan aksi penyerbuan dan pengrusakan dan pembakaran terhadap pura tersebut oleh ratusan massa pada Ahad, 13 Januari 2008. Tuntutan massa adalah penghentian pembangunan pura itu yang disebut-sebut bakal menjadi pura terbesar se-Asia Tenggara. ${ }^{48}$

Lalu, bagaimana sikap dan tingkat keterlibatan tuan guru dalam kasus tersebut? Sebenarnya, jika dirunut aksi kekerasan itu tidak berdiri sendiri sebagai suatu kasus, bukan insiden spontan. Jauh sebelumnya, tepatnya pada 29 Oktober 2007, sudah ada upaya penggalangan resmi oleh MUI NTB untuk menolak pembangunan pura tersebut. Penggalangan itu dilakukan dalam suatu pertemuan terbuka di Masjid Raya At-Taqwa Mataram. Pertemuan dihadiri anggota MUI se-NTB dan juga sejumlah tuan guru berpengaruh. Tema utama pertemuan memang seputar pembangunan pura itu. Berdasar hasil pertemuan itu MUI lalu merekomendasikan tiga hal diantaranya, yakni "mendesak Pemda NTB dan aparat keamanan untuk membatalkan pembangunan pura tersebut karena telah melecehkan citra Lombok yang berjuluk 'pulau seribu masjid." 49

Lalu, bagaimana sikap pemerintah? Bisa ditebak, sekali lagi, pemerintah mulai pusat hingga daerah rapi jali kompak berpihak pada komunitas Muslim yang notabene mayoritas di Lombok. Menteri Agama Maftuh Basuni, dalam satu kesempatan, menyatakan bahwa pembangunan tempat ibadah atau pura terbesar se-Asia Tenggara di Nusa Tenggara Barat (NTB) merupakan wacana yang berlebihan. Menurutnya, membangun tempat ibadah harus disesuaikan dengan kebutuhan umat

${ }^{47}$ Lombok Post, Edisi Senin, 15 September 2008.

${ }^{48}$ Data seputar kontroversi pembangunan pura Sangkareang tersebut dan penolakan sebagian masyarakat Muslim serta aksi perusakan-penyebuan oleh sekelompok massa diikutip dari http://www.opensubscriber.com/ message/mediacare@yahoogroups.com/8410154.html.

49 http://www.mail-archive.com/hindu-dharma@itb.ac.id/ msg01205. html, diakses pada 18 Desember 2008, 10.46 WIB. 
setempat dan tidak boleh berlebihan. Secara implisit, Basuni memang menghendaki penghentian pembangunan pura tersebut dengan alasan dapat menimbulkan kesalahpahaman dan konflik. ${ }^{50}$ Pandangan sedemikian lalu diekori oleh pejabat lokal, seperti Kepala Kantor Wilayah Departemen Agama NTB, Drs. H. Lalu Mahfudz, menganjurkan penghentian pembangunan pura tersebut mengingat penolakan masyarakat (Muslim) setempat dan juga karena dinilai tak berijin. ${ }^{51}$

Keempat, "pembiaran" atas kasus-kasus konflik antarumat beragama. Di Lombok, potensi benturan antarumat beragama selalu merupakan ancaman latent. Dan, preseden historisnya bukan tak pernah ada. Tunjuk misal, pertikaian antara etnis Samawa (Muslim) dan Bali (Hindu) tahun 1980 yang berlanjut menjadi perselisihan historis keduanya di kampung Taliwang Cakranegara dan sekitarnya, konflik antara masyarakat Muslim Sasak (desa Kediri) dan Hindu Bali (desa Jagerage) pada 1990an, rusuh yang berujung pembakaran sejumlah rumah ibadah di kota Mataram pada 17 Januari 2000, dan pertikaian antarkampung antara Karang Tapen (Muslim) dengan Karang Ledek (Hindu) pada 2003 lalu. ${ }^{52}$ Sejauh itu memang tak terjumpai data verifikatif yang menunjukkan keterlibatan aktiflangsung tuan guru sebagai provaktor konflik. Hanya saja, sikap "membiarkan" dengan tidak mengecam kerusuhan 17 Januari 2000, misalnya, yang banyak merugikan komunitas Kristiani dan etnis Tionghoa bakal menjadi andil tak langsung tuan guru dalam eskalasi konflik di masa-masa datang. ${ }^{53}$ Sikap diam

${ }^{50}$ Lihat "Menag: Berlebihan Bangun Pura Terbesar Asia Tenggara di NTB" dalam situs http://news.antara.co.id/arc/2007/11/20/menagberlebihan-bangun-pura-terbesar-asia-tenggara-di-ntb/, diakses pada 18 Desember 2008, 10.49 WIB.

${ }^{51}$ Lihat berita "Pembangunan Pura Terbesar di Asia Dihentikan" yang termuat dalam http://www.indonesia.go.id/id/index.php?option=com_ content\&task $=$ view\&id $=1694 \&$ Itemid $=682$, diakses pada 18 Desember 2008, 10.42 WIB.

52Untuk pemetaan konflik-konflik bernuansa agama di Lombok, lihat Asnawi, "Konflik dan Karakteristiknya," Makalah (tidak diterbitkan), Mediation Centre IAIN Mataram (2004): 1-8.

${ }^{53}$ Lebih jauh mengenai huru-hara yang lazim disebut "tragedi 171" tersebut lihat seutuhnya hasil penelitian Ahmad Amir Aziz, dkk. yang relatif 
mereka bukan mustahil dimaknai masyarakat sebagai sikap "setuju" atas setiap prilaku rusuh yang mengancam harmoni kehidupan keberagamaan di Lombok.

Terakhir, kelima, stigmatisasi "liberal" atas pemikiran keislaman yang kritis-progresif di banyak kesempatan, terutama di forum khut bah Jumat dan pengajian umum. Pihak yang disasar dari stigmatisasi ini bukan hanya individu atau komunitas penganjur berpikir kritis, melainkan juga institusi-institusi tertentu. Secara institusional, institusi pendidikan yang kerap menjadi sasaran stigmatisasi adalah Institut Agama Islam Negeri (IAIN) Mataram. Logis, karena kebanyakan kampanye "Islam kritis" dimulai dari sini. Akibatnya, aneka tuduhan seperti "agen Zionis" atau "komprador Barat" atau "lembaga pemurtadan" menjadi rutin dilekatkan.

Secara keseluruhan stigmatisasi tersebut adalah bentuk kekerasan intelektual yang didengung-dengungkan atas nama agama. Ujungnya, penistaan teologis berupa tuduhan "sesat dan menyesatkan", "haram hidup di Lombok", dan sejenisnya. Karena pelakunya kebanyakan tuan guru, stigmatisasi ini efektif mengunci ruang gerak pemikiran Islam kritis di area publik dan secara institusional juga relatif berhasil membunuh karakter (character assassination) sekaligus mendegradasi citra IAIN di mata masyarakat. Jelas ini bukan cuma ancaman bagi kebebasan berpikir tapi juga kebebasan beragama, dalam arti kebebasan memaknai agama anutan.

Dalam beberapa kasus, sejumlah tuan guru mengambil inisiasi berkolabirasi dengan negara. Upaya strategis berkolaborasi dengan pemerintah menampak terutama dalam kasus "pengislaman" kaum Wetu Telu dan upaya pelarangan atas Jemaat Ahmadiyah. Dalam pada itu, mereka memasuki institusiinstitusi keagaman bentukan negara seperti MUI dan FKUB (Forum Kerukunan Umat Beragama). Melalui dua institusi itu tuan guru bergerak semakin efektif mempersempit ruang gerak wacana kebebasan beragama. Semakin bergairah menentukan

berhasil merekonstruksi kronologi kejadian beserta penyebabnya juga ekses lanjut yang ditimbulkan. Versi artikelnya dimuat di Jurnal Ulumuna STAIN Mataram Volume VIII Edisi 14 Nomor 2 (Juli-Desember, 2004): 300-17 berjudul "Kerusuhan Bernuansa Agama 17 Januari di Lombok". 
apa yang boleh dan tak boleh, mana yang sesat dan yang selamat, mana yang salah dan yang benar. Di atas semua itu Tuhan tengah dipertaruhkan di hadapan kemanusiaan yang terus terkoyak di Lombok, di pulau yang masyarakat Muslim-nya bangga menyebutnya "pulau seribu masjid".

\section{Catatan Akhir}

Menyikapi tesis di atas, terdapat setidaknya empat saran yang dapat diajukan. Pertama, penting bagi tuan guru untuk segera mereorientasi paradigma dakwahnya. Reorientasi ini diarahkan pada pengalihan paradigmatik dakwah dari eksklusivisme ke inklusivisme. Di titik ini tuan guru seyogyanya menyadari bahwa untuk konteks Lombok suara mereka relatif masih dianggap suara Tuhan di bumi, "vox tuan guru vox der". Karena itu sikap arif dan bijaksana dalam memanfaatkan otoritas teologis dan kultural adalah penting agar tidak justru mencipta disharmoni sosial-keagamaan.

Kedua, revitalisasi terus menerus sikap-sikap inklusif dalam beragama. Harus disadari bahwa dalam konteks kehidupan beragama, dibutuhkan selalu pengetengahan kesadaran akan pluralisme dan multikuturalisme di ruang publik. Dan tuan guru menjadi salah satu kunci utama dalam proses ke arah itu. Ini mendesak, mengingat otoritas tuan guru begitu determinan, bahkan dominan, dalam dinamika sosial keagamaan masyarakat di Lombok. Alangkah mencekamnya bila otoritas itu dimanfaatkan secara semena-mena dengan mengabaikan prinsipprinsip resiprositas, yakni sikap saling menghargai atau menghormati antarumat beragama sebagaimana dipanggul pluralisme dan multikulturalisme.

Ketiga, forum-forum dialog dan kerja sama antaragama juga perlu terus digalakkan guna memediasi diversitas kepentingan, termasuk kepentingan teologis. Forum-forum sedemikian bernilai strategis untuk mengeliminasi segenap potensi konflik antarumat beragama. Melalui forum demikian pula tuan guru dapat memainkan peran profetiknya untuk menjamin hubungan antaragama berlangsung harmonis sekaligus mengawal praksis kebebasan beragama secara lebih produktif. 
Dan, keempat, menyangkut sikap negara di tengah (potensi) centang-perenang hubungan antaragama dan tercederainya cita kebebasan beragama. Dalam hal ini, pemerintah dituntut konsisten memainkan peran "primordial"-nya, yaitu sebatas memediasi dan memfasilitasi kepentingan warga, dan bukan mengintervensi area privat mereka. Pemerintah harus mulai belajar menegakkan konstitusi. Harus bersikap tegas terhadap setiap tindak kekerasan fisik dan intelektual atas nama agama. Menegakkan hukum, tidak melakukan pembiaran (crime by omission) lagi terhadap kasus-kasus pelanggaran kebebasan beragama. Pemerintah harus konsisten menjamin hak setiap warganya untuk merdeka memilih dan menghayati agamanya masing-masing.

Tanpa menyegerakan perwujudan minimal empat saran tersebut, rasanya umat Islam bakal kesulitan membantah sinisme A.N. Wilson, seorang novelis dan wartawan masyhur dari Inggris, atas signifikansi sosial agama berikut:

" ... It might be truer to say that the love of God is the root of all evil. Religion is the tragedy of mankind. It appeals that is noblest, purest, loftiest in human spirit, and yet there scarcely exist a religion, which has not been responsible for wars, tyrannies and suppression of the truth. Marx described it as the opium of the people; but it much deadlier than opium. It does not send people to sleep. It excites them to persecute one another, to exalt their own feelings and opinions above those of others, to claim for themselves a possession of the truth." 54

Rasanya memang sudah terlalu sering kita bertikai dan mengalirkan darah. Sudah waktunya kita mulai belajar menjadikan agama sebagai alasan mencipta kedamaian, dan

${ }^{54}$ (... Mungkin lebih benar lagi kalau dikatakan bahwa cinta akan Tuhan adalah akar segala kejahatan. Agama adalah tragedi bagi umat manusia. Ia mengajak kepada yang paling luhur, paling murni, paling tinggi dalam jiwa manusia, tapi nyaris tidak ada satu pun agama yang tidak ikut bertanggungjawab atas berbagai peperangan, tirani, dan penindasan atas kebenaran. Marx menggambarkan agama sebagai candu rakyat; tetapi agama jauh lebih berbahaya daripada candu. Agama tidak membuat orang tertidur. Agama mendorong orang untuk menganiaya sesamanya, untuk mengagungkan perasaan dan pendapat mereka sendiri atas perasaan orang lain, untuk mengklaim diri mereka sendiri sebagai pemilik kebenaran). Lihat A.N. Wilson, Against Religion: Why We Should Try to Live Without It (London: Chatto and Windus, 1992), 1. 
bukan alasan untuk saling berseteru, menang-menangan, dan memaksakan keimanan! Maka, penting disadari bahwa agama adalah suatu inspirasi, bukan sebuah aspirasi. ${ }^{55}$ Allah swt saja bilang, 56 "Jikalau Tuhanmu menghendaki, tentulah beriman semua orang di muka bumi seluruhnya. Maka, apakah kamu (hendak) memaksa manusia supaya mereka beriman semuanya?".

\section{Daftar Pustaka}

Ahmad Amir Aziz, Pemikiran dan Pola Dakwah TGKH Muhammad Zainuddin Abdul Madjid, Laporan Penelitian (Mataram: P3M STAIN Mataram, 1999). , dkk. "Kerusuhan Bernuansa Agama 17 Januari di Lombok," Jurnal Ulumuna, vol. VIII, edisi 14, no. 2 (JuliDesember, 2004): 300-17.

Abdurrahman Wahid, "Benarkah Kyai Membawa Perubahan Sosial?: Sebuah Pengantar," dalam Kyai dan Perubahan Sosial, Hiroko Horikoshi, ter. Umar Basalim dan Andy Muarly Sunrawa (Jakarta: Perhimpunan Pengembangan Pesantren dan Masyarakat, 1987): xi-xx.

A.N. Wilson, Against Religion: Why We Should Try to Live Without It (London: Chatto and Windus, 1992).

Asnawi, "Konflik dan Karakteristiknya," Makalah (tidak diterbitkan), Mediation Centre IAIN Mataram (2004): 1-8.

Asri Oktavianty Wahono, dkk., Reformasi Hukum terhadap Kebijakan Diskriminasi Ras dan Etnis di Indonesia (Jakarta:

Solidaritas Nusa Bangsa - The Asia Foundation, 2003).

Baharuddin, Nabdlatul Wathan dan Perubahan Sosial (Yogyakarta:

Genta Press, 2007).

Clifford Geertz, The Religion of Java (New York: Free Press, 1960). , "The Javanese Kijaji: The Changing Role of a

Cultural Broker," Comparative Studies on Society and History, II, 2 (January, 1960): 228-49.

${ }^{55}$ Frase Gus Dur, dikutip dari Maulidin al-Maula (ed.), Involusi Transisi (Surabaya: éLSAD, 2001), 135.

${ }^{56}$ Qs. Yûnus (10): 99. 
Diana L. Eck, A New Religious America: How a "Christian Country" Has Become the World's Most Religiously Diverse Nation (New York: Harper San Francisco, 2001).

Ernest Gellner, Postmodernism, Reason, and Religion (London: Routledge, 1993).

Erni Budiwanti, Islam Sasak: Wetu Telu versus Waktu Lima, ter. Noor Cholis dan Hairus Salim HS (Yogyakarta: LKíS, 2000).

Fathurrahman Muhtar, "Gerakan dan Pemikiran Dakwah Kiai Hamzanwadi dalam Bidang Pendidikan (1934-1997)," Jurnal Tasamuh, vol. II, no. 1 (Juni, 2004): 77-101.

Fawaizul Umam, Antara Membina dan Memperbanyak Umat: Pola Penyiaran Agama Hindu dan Islam di Kota Mataram, Laporan Penelitian (Mataram: P3M STAIN Mataram, 2004). , dkk. Membangun Resistensi, Merawat Tradisi: Modal Sosial Komunitas Wetu Telu (Mataram: LKIM IAIN Mataram, 2006). ,"Membaca Persepsi, Menakar Prospek: Sebuah Catatan Reflektif tentang Ulama dan Pemberdayaan Perempuan di Lombok," Jurnal EGALITA, vol. II, no. 1 (2007): 1-24.

"Menakar Kebebasan Beragama di Indonesia:

Rekonstruksi Peran Negara, Revitalisasi Inklusivitas Beragama", Makalab (tidak diterbitkan), disampaikan pada Annual Conference on Islamic Studies 2007 (21-24 November 2007) Direktorat Pendidikan Tinggi Islam Dirjen Pendidikan Islam Depag RI di Pekanbaru Riau, Jumat, 23 November 2007: 1-17.

Franklin I. Gamwell, The Meaning of Religious Freedom: Modern Politics and the Democratic Resolution (Albany, New York: State University of New York Press, 1995).

F. Wahono Nitiprawira, Teologi Pembebasan: Sejarah, Metode, Praksis, dan Isinya (Jakarta: Pustaka Sinar Harapan, 1987).

Harapandi Dahri, Wali dan Keramat dalam Persepsi Tradisional dan Modern (Mataram: IAIN Mataram Press, 2004).

Hiroko Horikoshi, Kyai dan Perubahan Sosial, ter. Umar Basalim dan Andy Muarly Sunrawa (Jakarta: Perhimpunan Pengembangan Pesantren dan Masyarakat, 1987). 
J. A. C. Brown, "Propaganda and Communications," dalam Creating Social Change, 360-70.

John Hick, "Religious Pluralism", The Encyclopedia of Religion, vol. V, ed. Mircea Eliade (New York: Simon \& Schuster Macmillan, 1995).

Kuntowijoyo, Muslim Tanpa Masjid: Esai-esai Agama, Budaya, dan Politik dalam Bingkai Strukturalisme Transendental (Bandung: Mizan, 2001).

Leena Marjatta Avonius, Reforming Wetu Telu: Islam, Adat, and the Promises of Religionalism in Post-New Order Lombok, Ph.D Dissertation (Universiteit Leiden, 2001).

Louise Lamphere, "The Domestic Sphere of Women and the Public World of Man: The Strenghts and Limitations of an Antropological Dictionary," dalam Gender in Cross-Cultural Perspective, ed. Caroline B. Brettel dan Carolyn F. Sargent (New Jersey: Prentice Hall, 1993): 67-75.

Lukman al-Hakim, Peranan Ulama dalam Pengembangan Syariat Islam di Lombok, Laporan Penelitian (Mataram: IAIN Sunan Ampel Mataram, 1995).

Maulidin al-Maula (ed.), Involusi Transisi (Surabaya: éLSAD, 2001).

Michel Foucault, The History of Sexuality: An Introduction, ter. Robert Hurley, vol. 1 (New York: Pantheon Books, 1978).

M. Munandar Soelaiman, Dinamika Masyarakat Transisi: Mencari Alternatif Teori Sosiologi dan Arah Perubahan (Jogjakarta: Pustaka Pelajar, 1998).

Mustain, Hubungan Hindu-Muslim di Kota Mataram (Kajian terbadap Potensi Konflik dan Integrasi Hubungan Antaragama), Laporan Penelitian (Mataram: P3M STAIN Mataram, 2003).

Nusa Tenggara Barat Dalam Angka 2005 (Mataram: Badan Pusat Statistik Provinsi NTB, 2005).

Raimundo Panikkar, Dialog Intrareligius, ter. J. Dwi Helly Purnomo dan P. Puspobinatmo (Jogjakarta: Kanisius, 1994).

Stephen K. Sanderson, Sosiologi Makro: Sebuah Pendekatan terhadap Realitas Sosial, ter. Farid Wajidi dan S. Meno (Jakarta: Rajawali press, 1993).

Suprapto, "Dakwah Islamiyah dalam Perspektif Pluralisme Agama (Analisis Isi Khutbah Jumat pada Masjid-masjid di 
Kota Mataram," Jurnal Tasamuh, vol. 2, no. 1 (Desember, 2004): 61-78.

"Pesantren dan Pemberdayaan Masyarakat:

Menimbang Aktivitas Dakwah bi al-Hal Pesantren di Lombok," Jurnal Tasamuh, vol. IV, no. 1 (Desember, 2006), 87-108.

Sven Cederroth, The Spell of the Ancestors and the Power of Mekekah: A Sasak Community on Lombok (Gögteborg, Sweden: ACTA Universitatis Gothoburgensis, 1981).

Terrence W. Tilley, Postmodern Theologies and Religious Diversity (Maryknoll, New York: Orbis Book, 1996).

Thomas Kuhn, The Structures of Scientific Revolution (Chicago: the University of Chicago Press, 1970).

Tore Lindholm, W. Cole Durham, Jr., Bahia G. Tahzib-Lie, dan

Nazila Ghanea, "Introduction," Facilitating Freedom of Religion or Belief: A Deskbook, ed. Tore Lindholm, W. Cole Durham, Jr., dan Bahia G. Tahzib-Lie (Leiden, The Netherlands: Koninklijke Brill NV, 2004): xxvii-lxxiv.

Torgny T. Segerstedt, The Nature of Social Reality (Stockholm: Svenska Bokforlaget, 1966).

Lombok Post, 15 September 2008.

"What is Religious Freedom?" dalam situs http://www.mindspring.com/ careyb/rf_defn.html,.

"International Covenant on Civil and Political Rights" dalam situs http://www.enwikisource.org/wiki/International_ Covenant_onCivil_and_Political_Rights.

"Universal Declaration of Human Rights" dalam website PBB (UNO), http://www.un.org/Overview/rights.html.

"Menapaki Bangsa yang Kian Retak" (Laporan Tahunan The WAHID Institute tentang Pluralisme Beragama dan Berkeyakinan di Indonesia Tahun 2008) dalam http://www.wahidinstitute.org/files/_docs/Laporan\%20Plu ralisme $\% 202008 \% 20$ WahidInstitute.pdf.

"Warga Serang Anggota Ahmadiyah Lombok Timur" dalam http://m.infoanda.com/readnewstech.php.

"Jemaat Ahmadiyah Sulit Kembali ke Kampungnya," dalam http://www.antara.co.id/arc/2008/6/12/jemaatahmadiyah-sulit-kembali-ke-kampungnya/. 
"Menag: Berlebihan Bangun Pura Terbesar Asia Tenggara di NTB"dalamhttp://www.news.antara.co.id/arc/2007/11/20 /menag-berlebihan-bangun-pura-terbesar-asia-tenggara-di$\mathrm{ntb} /$.

"Pembangunan Pura Terbesar di Asia Dihentikan" dalam http://www.indonesia.go.id/id/index.php?option=com_ content\&task $=$ view\&id $=1694 \&$ Itemid $=682$.

www.komnasham.go.id/portal/files/laporan\%20kajian\%20ahm adiyah.pdf.

"Ajaran Ahmadiyah Belum Dapat Diterima di Lombok," dalam http://www.kompas.com/utama/news/0602/07/075627_ .htm.

"Ulama NTB Desak Ahmadiyah Dilarang," dalam http://www.tempointeraktif.com/hg/nusa/2007/04/18/ brk,20070418-98282,id.html.

http://www.opensubscriber.com/message/mediacare@yahoogr oups.com/8410154.html.

http://www.mailarchive.com/hindudharma@itb.ac.id/ msg01205.html. 